\section{Ipomoea batatas 'Margarita'}

\author{
Allan M. Armitage ${ }^{1}$ and James M. Garner ${ }^{2}$ \\ Department of Horticulture, University of Georgia, Athens, GA, 30602
}

Sweet potato [Ipomoea batatas (L.) Poir] has been a staple food crop for centuries, providing an important source of carbohydrates, particularly in the tropics. Plants have been selected for tuber characteristics, including yield, carbohydrate content, color, and taste (Wang, 1982). The ornamental value of Ipomoea foliage was overlooked by the landscape and greenhouse industries until recently, when the purple foliaged 'Blackie' was promoted in the literature of the greenhouse trade (Armitage, 1995, 1999).

Ipomoea batatas 'Margarita' is a chartreuse-leafed sweet potato that maintains the chartreuse color throughout the growing season and was released from the Dept. of Horticulture New Crops Program at the Univ. of Georgia in 1996.

\section{Origin}

'Margarita' was discovered in the garden of Mr. Hunter Stubbs in Raleigh, N.C. He provided a single plant in Fall 1995 that was increased by vegetative cuttings in a greenhouse at the Univ. of Georgia. 'Margarita' has appeared in various catalogs as 'Marguarita' and 'Margaurite'.

\section{Description}

The leaves are three-lobed to cordate and alternate, with a cordate base and a broadly acuminate apex (Fig. 1). The middle lobe is generally 3 times as long as the basal lobes, which are 13 to $15 \mathrm{~cm}$ long $\times 14$ to $15 \mathrm{~cm}$ wide, borne on round petioles, 25 to $29 \mathrm{~cm}$ long. The leaf is chartreuse, (yellow-green group, 144A, on the Royal Horticultural Society Color Chart) (Royal Horticultural Society, 1966). The plants exhibit a trailing, prostrate habit, reaching 18 to $40 \mathrm{~cm}$ in height. Depending on temperature, stems grow up to $20 \mathrm{~m}$ long (Fig. 1). The plant has failed to produce flowers outdoors, regardless of the environmental conditions.

Received for publication 28 Dec. 1999. Accepted for publication 28 June 2000 . The cost of publishing this paper was defrayed in part by the payment of page charges. Under postal regulations, this paper therefore must be hereby marked advertisement solely to indicate this fact.

${ }^{1}$ Professor of Horticulture.

${ }^{2}$ Graduate Research Assistant.

\section{Performance}

A single plant, labeled as 'Margarita', was transplanted to the Dept. of Horticulture trial garden in Spring 1996. It grew vigorously, producing over two dozen stems, each stem 8 to $12 \mathrm{~m}$ long by season's end. The bright chartreuse foliage was highly visible from a distance, a trait highly sought by landscapers. The plants are annual in Athens, Ga., U.S. Dept. of Agriculture (USDA) zone $7 \mathrm{~b}$, although storage roots will survive mild winters. Plants should be considered as horticultural annuals, and vegetative cuttings may be rooted for overwintering.

Open houses for commercial growers were held at the Univ. of Georgia Horticulture Gardens during the growing seasons 1996 through 1998 and cuttings of 'Margarita' were provided to interested growers for further propagation and evaluation.

Another chartreuse form called 'Sulphur' was also evaluated and its performance was compared with that of 'Margarita'. Plant size data for both cultivars were collected in 1996 from three plants of each cultivar growing in the Univ. of Georgia Horticulture Gardens. Plants of 'Sulphur' were similar to 'Margarita'
Fig. 1. Leaf shape of Ipomoea batatas 'Margarita'. in color, although they were more upright and less vigorous (Table 1). 'Margarita' may have been a sport of 'Sulphur'.

\section{Availability}

Plants are available through major plant brokers and distributors as well as independent greenhouses throughout the country.

Table 1. Comparison of plants of Ipomoea batatas 'Sulphur' and 'Margarita' in trial garden, Athens, Ga.

\begin{tabular}{lcc}
\hline \hline Cultivar & Height $^{ }(\mathrm{cm})$ & Width $(\mathrm{m})$ \\
\hline Margarita & $30(3.2)$ & $5.2(4.5)$ \\
Sulphur & $45(4.1)$ & $7.9(4.6)$ \\
Significance & $*$ & $*$
\end{tabular}

${ }^{2}$ Plants placed in garden Apr. 1996 and measured 15 Sept. 1996. Means represent three separate measurements of three plants of each cultivar. Numbers in parenthesses represent the SE about the mean.

*Analysis of variance significant, $P \leq 0.05$.

\section{Literature Cited}

Armitage, A.M. 1995. Specialty annuals. Greenhouse Grower 13(5):99-101.

Armitage, A.M. 1999. Sweet potato. Greenhouse Grower 17(3):103-104.

Royal Horticultural Society. 1966. Royal Horticultural Society colour chart. Royal Hort. Soc. London.

Wang, H. 1982. The breeding of sweet potatoes for human consumption, p. 297-331. In: R.L. Villareal and T.D. Griggs (eds.). Sweet potato, Proc. First Intl. Symp. Asian Veg. Res. and Dev. Ctr. Taiwan.

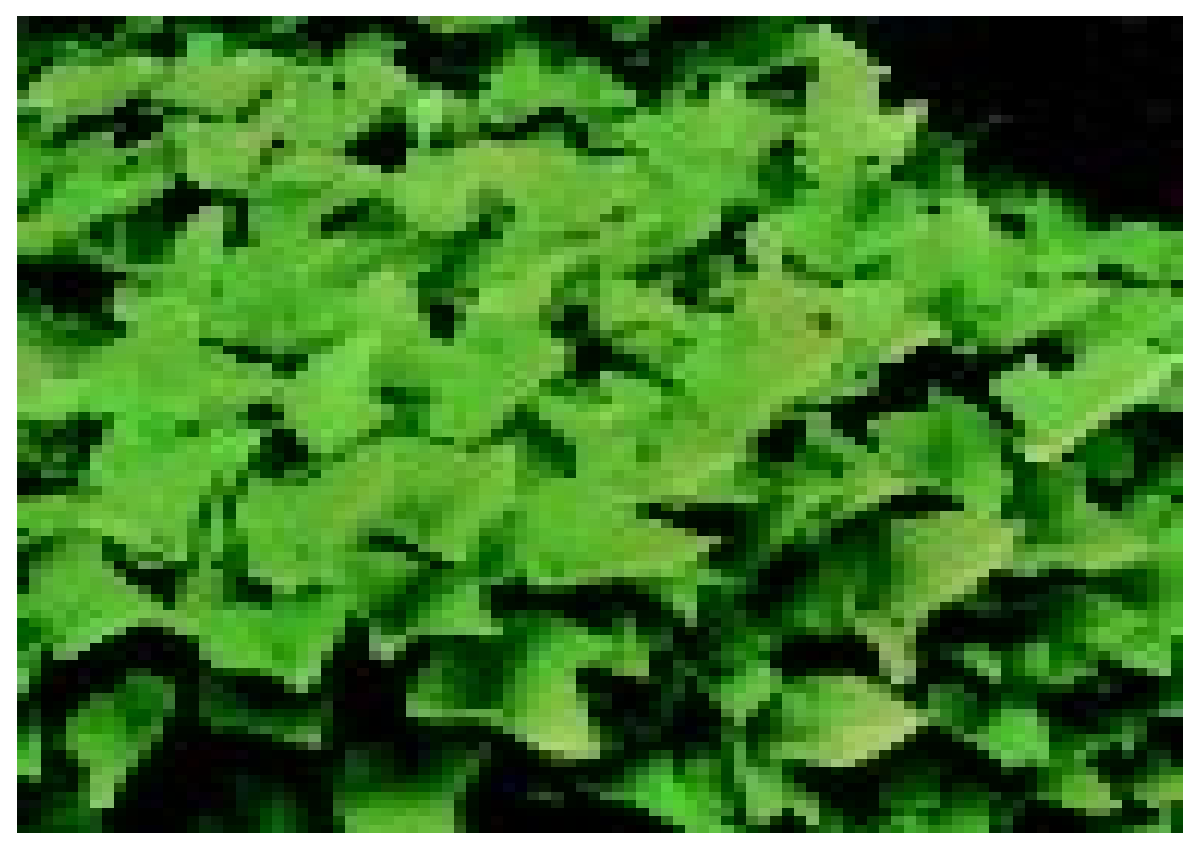

